\title{
Correction to: Reduced sphingolipid hydrolase activities, substrate accumulation and ganglioside decline in Parkinson's disease
}

Mylene Huebecker ${ }^{1}$, Elizabeth B. Moloney ${ }^{2}$, Aarnoud C. van der Spoel ${ }^{3}$, David A. Priestman ${ }^{1}$, Ole Isacson ${ }^{2 *}$, Penelope J. Hallett ${ }^{2^{*}}$ and Frances M. Platt ${ }^{1 *}$

\section{Correction to: Mol Neurodegener}

$$
\text { https://doi.org/10.1186/s13024-019-0339-z }
$$

The original article [1] contains an error in the y-axes of Fig. 8's sub-figures whereby 'CSF' is mistakenly mentioned instead of 'serum'.

The correct version of Fig. 8 can be viewed ahead and should be considered in place of the original Fig. 8 .

\section{Author details}

'Department of Pharmacology, University of Oxford, Oxford OX1 3QT, UK. ${ }^{2}$ Neuroregeneration Institute, McLean Hospital / Harvard Medical School, Belmont, MA 02478, USA. ${ }^{3}$ Departments of Pediatrics and Biochemistry \& Molecular Biology, Atlantic Research Centre, Dalhousie University, Halifax, NS B3H 4R2, Canada.

Published online: 15 January 2020

\section{Reference}

1. Huebecker M, Moloney ER, van der Spoel AC, Priestman DA, Isacson O, Hallett PJ, Platt FM. Reduced sphingolipid hydrolase activities, substrate accumulation and ganglioside decline in Parkinson's disease. Mol Neurodegener. 2019;14:40 https://doi.org/10.1186/s13024-019-0339-z.

*Correspondence: isacson@hms.harvard.edu; phallett@mclean.harvard.edu; frances.platt@pharm.ox.ac.uk

${ }^{2}$ Neuroregeneration Institute, McLean Hospital / Harvard Medical School, Belmont, MA 02478, USA

'Department of Pharmacology, University of Oxford, Oxford OX1 3QT, UK

Full list of author information is available at the end of the article

(c) The Author(s). 2020 Open Access This article is distributed under the terms of the Creative Commons Attribution 4.0 International License (http://creativecommons.org/licenses/by/4.0/), which permits unrestricted use, distribution, and reproduction in any medium, provided you give appropriate credit to the original author(s) and the source, provide a link to the Creative Commons license, and indicate if changes were made. The Creative Commons Public Domain Dedication waiver (http://creativecommons.org/publicdomain/zero/1.0/) applies to the data made available in this article, unless otherwise stated. 

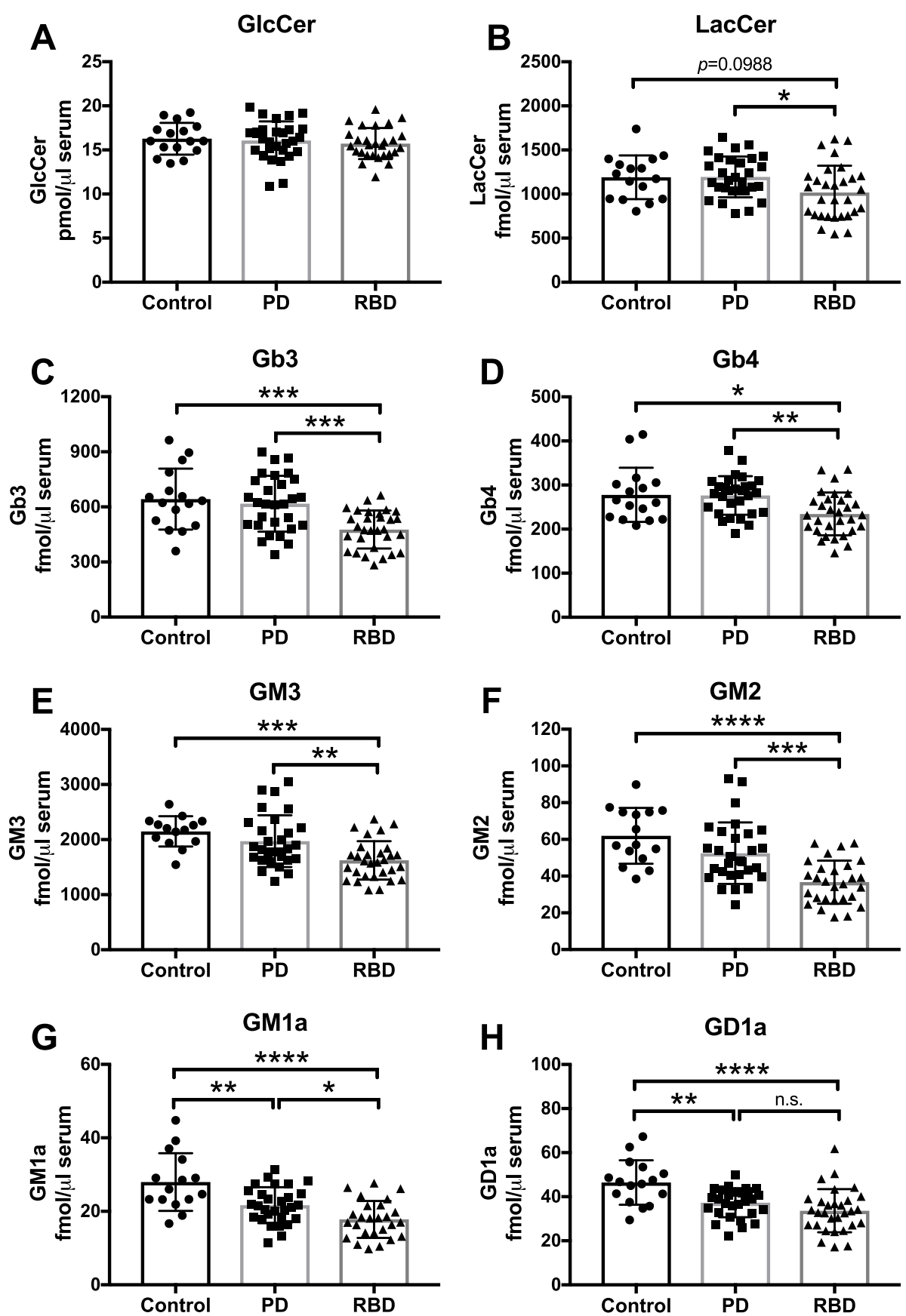

Fig. 8 Significant reduction in GM1a and GD1a levels in serum from PD patients and significant reduction in all measured glycosphingolipids, except GlcCer, in serum from RBD patients. Levels of GlcCer (a), LacCer (b), Gb3 (c), Gb4 (d), GM3 (e), GM2 (f), GM1a (g) and GD1a (h) were determined in serum samples from control subjects $(n=15)$, PD patients $(n=30)$ and age-matched RBD patients $(n=30)$ with NP-HPLC $\left({ }^{*}=p<\right.$ $0.05,{ }^{* *}=p<0.01,{ }^{* * *}=p<0.001,{ }^{* * *}=p<0.0001$, one-way ANOVA). Data are presented as mean \pm SD 